\title{
Analisis Pengendalian Inventori Dengan Klasifikasi ABC dan EOQ Pada PT Nissan Motor Distributor Indonesia
}

\author{
Darfial Guslan ${ }^{1}$, Ibrahim Saputra ${ }^{2}$ \\ ${ }_{1}$ Program Studi Logistik Bisnis, Politeknik Indonesia \\ email: darfialguslan@poltekpos.ac.id \\ ${ }_{2}$ Program Studi Logistik Bisnis, Politeknik Indonesia \\ email: ibrahim_saputra@gmail.com
}

\begin{abstract}
PT Nissan Motor Distributor Indonesia merupakan perusahaan yang bergerak dalam penjualan suku cadang resmi Nissan. Perusahaan menyimpan berbagai jenis suku cadang resmi Nissan, diantaranya suku cadang yang digunakan pada unit Grand Livina. Permasalahan yang dialami oleh PT Nissan Motor Distributor Indonesia ini adalah mengenai tingkat persediaan yang cukup tinggi terhadap suku cadang yang digunakan pada unit Grand Livina, kondisi seperti ini tentunya menjadi salah satu penyebab pemborosan dalam segi biaya di perusahaan. Masalah tersebut berawal pada penentuan kuantitas pemesanan yang kurang tepat, sehingga menyebabkan pada besarnya total biaya persediaan.

Dalam penelitian ini dilakukan pendekatan dengan menggunakan metode EOQ multi item. Untuk mempermudah penelitian maka dilakukan pengelompokan 1336 suku cadang kedalam tiga kelas berdasarkan klasifikasi ABC untuk mendapatkan suku cadang yang termasuk kedalam kategori kritis, yang kemudian dilanjutkan dengan melakukan perhitungan rencana kuantitas pemesanan suku cadang yang digunakan pada unit Grand Livina berdasarkan kebijakan perusahaan dan metode usulan.

Dari hasil perhitungan rencana kuantitas pemesanan berdasarkan metode usulan diperoleh jumlah suku cadang yang termasuk kedalam kategori kritis adalah 47,55\% dari total jumlah suku cadang dengan penyerapan dana sebesar 79,99\% dari total modal persediaan.
\end{abstract}

Kata Kunci : Suku Cadang, Kuantitas Pemesanan, Efisiensi Biaya, Analisis klasifikasi ABC, Economic Order Quantity (EOQ) Multi Item.

\section{PENDAHULUAN [Times New Roman 11 bold]}

\section{Latar Belakang Penelitian}

Berkaitan dengan keadaan perekonomian yang semakin berkembang ini banyak terjadi persaingan di berbagai bidang kehidupan, termasuk didalamnya persaingan dalam dunia bisnis. Banyak perusahaan yang saling berlomba untuk mendapatkan pangsa pasar, sehingga hal ini memacu perusahaan untuk berusaha terus maju dalam memperbaiki bisnisnya. Di samping itu dengan adanya kemajuan teknologi, perusahaan dituntut pula untuk dapat mengikuti perkembangan zaman agar tidak tertinggal dengan yang lainnya.

Pengendalian persediaan bahan baku merupakan salah satu aspek yang sangat penting bagi berlangsungnya kelancaran suatu produksi. Keberlangsungan proses produksi tidak akan berjalan jika tingkat persedian berada di dalam kondisi yang tidak tepat, artinya tingkat persediaan tidak dalam kondisi kekurangan persediaan (stock out) dan persediaan tidak dalam kondisi kebanyakan persediaan (over stock), Hal ini berlaku untuk semua industri terutama industri yang bergerak dalam bidang manufakturing.

PT Nissan Motor Indonesia (NMI) merupakan salah satu industri otomotif di tanah air yang melakukan kegiatan bisnis dalam penjualan, distribusi, dan penjualan suku cadang resmi Nissan. PT NMI ini memiliki beberapa departemen bisnis diantaranya, Nissan Head Office yang berperan sebagai manajemen pusat pada PT NMI yang berlokasi di MT Haryono, Jakarta, Nissan Technical Center yang berlokasi di TB Simatupang, Jakarta, dan Nissan Learning Center yang berlokasi di Gading Serpong, Tangerang, adapula Nissan Plant yang memiliki proses bisnis sebagai assembling point pada PT NMI, yaitu lokasi dimana PT NMI melakukan perakitan sebuah unit mobil sampai unit siap untuk dipasarkan, dan departemen bisnis yang terakhir adalah PT Nissan Motor Distributor Indonesia yang berlokasi di kawasan industri BIC, Purwakarta. 
PT Nissan Motor Distributor Indonesia (NMDI) didirikan pada tahun 1997 yang awalnya berlokasi didaerah Ancol, Jakarta. PT NMDI ini merupakan salah satu departemen bisnis dari PT NMI dan juga menjadi pusat penyimpanan suku cadang resmi Nissan. Kegiatan bisnis yang dilakukan PT NMDI ini antara lain melakukan pendistribusian dan penjualan suku cadang resmi Nissan kepada seluruh dealer resmi Nissan yang tersebar di Indonesia, sampai saat ini terdapat kurang lebih 98 dealer resmi Nissan dengan kapasitas produksi 90.000 unit per tahunnya.

Produk yang disimpan oleh PT NMDI berupa suku cadang resmi Nissan, diantaranya suku cadang untuk unit Grand Livina, March, Evalia, Serena, dan juga XTrail. Dari berbagai macam suku cadang yang disimpan didalam gudang PT NMDI ini, penulis melakukan analisa terhadap suku cadang yang digunakan untuk produk Grand Livina, produk ini diproduksi menggunakan sekitar 1336 jenis suku cadang.

Salah satu permasalahan yang terjadi di PT NMDI ini adalah permasalahan mengenai persediaan, dengan kondisi seperti ini maka PT NMDI memiliki tingkat persediaan yang cukup tinggi, dengan kata lain ada beberapa suku cadang yang stok barangnya menumpuk yang artinya perusahaan ini mengalami over stock. Sebagai contoh dapat dilihat dari data persediaan pada tahun periode 2018 berikutini :

Tabel 1.1 Persediaan tahun 2018

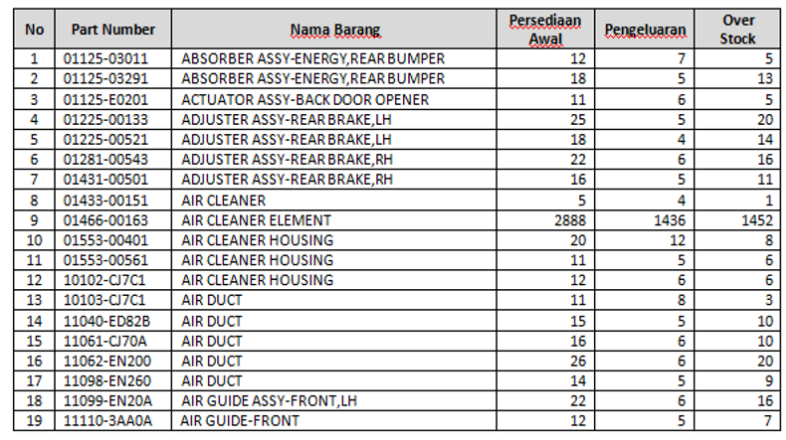

\section{Rumusan Masalah}

Berdasarkan identifikasi masalah yang telah diuraikan diatas, adapun perumusan masalah dalam penelitian ini adalah sebagai berikut

1. Jenis suku cadang manakah yang perlu diprioritaskan dalam pengendalian persediaan pada unit Grand Livina ?

2. Berapakah jumlah optimal persediaan dari suku cadang yang diprioritaskan pada unit Grand Livina?

3. Berapakah total cost yang seharusnya dikeluarkan oleh PT Nissan Motor Distributor Indonesia dengan pengadaan suku cadang pada unit Grand Livina yang optimal ?

\section{Tujuan Penelitian}

Berdasarkan rumusan masalah di atas maka tujuan penelitian yang ingin dicapai dalam penelitian ini adalah sebagai berikut :

1. Untuk mengetahui suku cadang manakah yang perlu diprioritaskan dalam pengendalian persediaan pada unit Grand Livina.

2. Untuk mengetahui jumlah optimal persediaan dari suku cadang yang diprioritaskan pada unit Grand Livina.

3. Untuk menetapkan total cost yang seharusnya dikeluarkan oleh PT Nissan Motor Distributor Indonesia dengan pengadaan suku cadang pada unit Grand Livina yang optimal.

\section{METODE PENELITIAN}

Metode yang akan digunakan dalam penelitian ini adalah metode pengendalian persediaan statistik. Penulis menggunakan metode pengendalian persediaan statistik karena metode ini menggunakan basis ilmu matenatika, statistika, dan optimasi sebagai alat bantu utama dalam menjawab permasalahan - permasalahan kuantitatif yang terjadi didalam sistem persediaan suku cadang di PT Nissan Motor Distributor Indonesia untuk pemecahan masalahnya, pertama penulis akan mengklasifikasikan semua suku cadang yang digunakan dalam unit mobil Grand Livina berdasarkan kekritisannya dengan menggunakan analisis ABC, selanjutnya untuk penetapan persediaan yang optimal metode yang digunakan adalah Economic Order Quantity Multi Item.

\section{Analisis Klasifikasi ABC}

Analisis ABC adalah pemilihan barang berdasarkan tingkat, penyerapan modal dengan menggunakan prinsip diagram pareto. Pada prinsipnya analisis $\mathrm{ABC}$ mengklasifikasikan jenis barang yang didasarkan atas tingkat investasi tahunan yang terserap didalam penyediaan persediaan, untuk setiap jenis barang.

Berdasarkan prinsip Pareto, barang dapat diklasifikasikan menjadi tiga kategori yaitu :

a. Kategori A (80-20)

Dalam kategori ini terdiri dari jenis barang yang menyerap dana sekitar $80 \%$ dari seluruh modal yang disediakan untuk inventory dan jumlah jenis barangnya sekitar 20\% dari semua jenis barang yang dikelola.

b. Kategori B (15-30)

Untuk kategori B ini terdiri dari jenis barang yang menyerap dana sekitar $15 \%$ dari seluruh modal yang disediakan untuk inventory (sesudah kategori A) dan jumlah jenis barangnya sekitar $30 \%$ dari semua jenis barang yang dikelola. 


\section{c. Kategori C (5-50)}

Sedangkan dalam kategori $\mathrm{C}$ ini terdiri dari jenis barang yang menyerap dana hanya sekitar 5\% dari seluruh modal yang disediakan untuk inventory (yang tidak termasuk kategori A dan B) dan jumlah jenis barangnya sekitar $50 \%$ dari semua jenis barang yang dikelola.

Untuk menghitung persentase kumulatif harga suku cadang setiap kelompok $\mathrm{ABC}$ adalah :

\section{Economic Order Quantity Multi Item}

EOQ multi item adalah teknik pengendalian permintaan beberapa jenis item yang optimal dengan biaya inventory serendah mungkin. Tujuan dari model EOQ adalah menentukan jumlah $\mathrm{Q}$ setiap kali pemesanan sehingga meminimasi total biaya persediaan.

Model EOQ multi item merupakan model EOQ untuk pembelian bersama (joint purchase) beberapa jenis item. Asumsi - asumsi yang digunakan dalam model EOQ multi item antara lain :

a. Tingkat permintaan untuk setiap item konstan dan diketahui dengan pasti

b. Waktu tunggunya sama untuk semua item, dimana semua item yang dipesan akan datang pada satu titik waktu yang sama untuk setiap siklus.

c. Biaya simpan, harga per unit, dan biaya pesan untuk setiap item diketahui.

d. Biaya pesan untuk masing - masing item adalah sama.

e. Item yang dianalisis bersifat independent.

\section{HASIL DAN PEMBAHASAN}

\section{Pengumpulan Data}

Berikut ini adalah data yang dibutuhkan dalam pemecahan masalah adalah sebagai berikut :

a. Data permintaan suku cadang unit Grand Livina tahun 2018

b. Data harga setahun terakhir dari masing - masing suku cadang unit Grand Livina.

c. Biaya yang berhubungan dengan masalah persediaan. Biaya - biaya yang berhubungan dengan persediaan suku cadang Grand Livina antara lain :

1. Biaya pemesanan suku cadang Grand Livina

a. Biaya Transportasi: Sebesar $2 \%$ dari item yang dipesan

b. PPn: 10\% dari item yang dipesan

Total Biaya Pemesanan: 12\% x Jumlah Item

Total biaya diatas merupakan biaya pemesanan yang dikeluarkan oleh PT Nissan Motor Distributor Indonesia dalam satu kali pemesanan.

2. Biaya penyimpanan suku cadang

Besarnya biaya penyimpanan tergantung pada jumlah barang yang disimpan di gudang. Biaya penyimpanan di PT Nissan Motor Distributor Indonesia merupakan biaya perawatan dan biaya penjagaan dikarenakan gudang di PT Nissan Motor Distributor Indonesia merupakan gudang milik sendiri di ketahui bahwa persentase biaya penyimpanan yang di tetapkan oleh perusahaan adalah sebesar 5\% : Total Biaya Penyimpanan : 5\% x Jumlah Item 3. Biaya kekurangan persediaan

Biaya kekurangan persediaan suku cadang unit Grand Livina dianggap tidak ada, karena perusahaan selalu mengantisipasi kekurangan persediaan. Jadi biaya kekurangan persediaan sebesar $0 \%$.

4. Waktu ancang - ancang

Waktu ancang - ancang adalah waktu antara pada saat pemesanan sampai dengan diterimanya pesanan tersebut oleh perusahaan. Waktu ancang - ancang (Lead Time) untuk setiap pemesanan suku cadang unit Grand Livina adalah 14 hari.

\section{Pengolahan Data}

Penentuan Suku Cadang Kritis

Untuk menghitung persentase kumulatif harga suku cadang setiap kelompok $\mathrm{ABC}$ adalah :

$$
\% \text { Kumulatif Harga }=\frac{\text { kumulatif harga setiap suku cadang }}{\text { total } \text { kumulatif harga suku cadang }} x
$$

Sebagai contoh perhitungan, penulis mencoba menghitung persentase kumulatif harga DISC ASSY-CLUTCH sebagai berikut :

$$
\% \text { Kumulatif Harga }=\frac{\mathrm{Rp} 336,102,000}{\mathrm{Rp} 12,646,430,000} \times 100 \%=2,66 \%
$$

Selanjutnya adalah melakukan perhitungan persentase kumulatif jumlah suku cadang unit Grand Livina. Sebagai contoh perhitungan, penulis mencoba menghitung persentase kumulatif jumlah DISC ASSY-CLUTCH sebagai berikut :

$$
\begin{gathered}
\% \text { Kumulatif Barang }=\frac{\text { kumulatif jumlah setiap barang }}{\text { Ssuku cadang }} \times \\
=\frac{417}{33406} \times 100 \%
\end{gathered}
$$

Berdasarkan hasil perhitungan dari tabel diatas maka dapat diketahui

Golongan A

Pengendalian lebih ditujukan pada golongan A, yaitu golongan yang menyerap modal persediaan yang sangat besar dari seluruh pengeluaran untuk pengadaan suku cadang unit Grand Livina selama tahun 2018. Jenis - jenis suku cadang dalam golongan ini berjumlah $47,55 \%$ dari jumlah keseluruhan suku cadang, dengan menyerap $79,99 \%$ dari modal yang terdapat dalam persediaan.

Golongan B

Golongan B menyerap 14,93\% dari modal yang tertanam pada seluruh persediaan suku cadang unit Grand Livina dan berjumlah $28,72 \%$ dari jumlah keseluruhan suku cadang.

Golongan C

Meliputi jumlah suku cadang yang berada diluar kedua golongan $\mathrm{A}$ dan golongan $\mathrm{B}$. Golongan $\mathrm{C}$ menyerap modal sekitar $4,98 \%$ dari modal yang tertanam pada persediaan suku cadang, dan jumlahnya meliputi $23,65 \%$ dari jumlah keseluruhan suku cadang. 
Penentuan Jumlah Suku Cadang Optimal

Penentuan jumlah pemesanan suku cadang optimal dilakukan untuk mendapatkan jumlah pemesanan suku cadang yang paling baik. Dimana perhitungan dilakukan dengan menggunakan metode economic order quantity (EOQ) multi item sebagai berikut :

$$
Q_{i}^{*}=\sqrt{\frac{2 D i A i}{h i}}
$$

Berdasarkan rumus diatas dapat diambil contoh perhitungan $Q_{i}{ }^{*}$ untuk suku cadang DISC ASSY-CLUTCH sebagai berikut :

$Q_{i} *=\sqrt{\frac{2(417 \times 12 \%)}{5 \%}}=45$

Penentuan Total Cost Persediaan

Penentuan total cost persediaan bertujuan untuk menentukan besarnya biaya persediaan yang harus dikeluarkan oleh perusahaan. Dalam penentuan besarnya keseluruhan biaya persediaan, terdapat biaya - biaya yang berkaitan diantaranya biaya pembelian, biaya pemesanan, dan biaya penyimpanan. Sehingga dapat dinyatakan dalam rumus berikut ini : $\mathrm{TC}(\mathrm{Q})=\mathrm{S}+\mathrm{P}+\mathrm{O}$

Dari rumus diatas dapat dijabarkan lagi menjadi rumus sebagai berikut:

$\mathrm{TC}(\mathrm{Q})=\sum \mathrm{S}+\sum \mathrm{P}+\sum \mathrm{O}$

1. Perhitungan Biaya Pembelian Optimal

Contoh perhitungan biaya pemebelian $(O)$ untuk suku cadang DISC ASSY-CLUTCH adalah sebagai berikut :

$$
\begin{aligned}
O & =D i \times C i \\
& =45 \times \mathrm{Rp} .806 .000 \\
& =\mathrm{Rp} .36 .270 .000
\end{aligned}
$$

Dari perhitungan biaya pembelian optimal diatas dapat diketahui total biaya pembelian optimal yaitu sebesar Rp. 5.630.959.000

2. Perhitungan Biaya Pemesanan Optimal

Contoh perhitungan biaya pemesanan untuk suku cadang DISC ASSY-CLUTCH dapat dihitung dengan menggunakan rumus sebagai berikut :

$\mathrm{P}=\mathrm{f} \times \mathrm{A}$

Dimana :

$\mathrm{f}=$ frekuensi pemesanan

$\mathrm{f}=\frac{D i}{Q *} \quad=\frac{417}{45}=9$

karena besarnya biaya pesan adalah $12 \%$ dari setiap harga barang yang dipesan maka,

$\mathrm{A}=(45 \times$ Rp. 806.000$) \times 12 \%=$ Rp. 4.352 .400

Jadi biaya pemesanan dapat diketahui sebagai berikut :

$\mathrm{P}=\mathrm{f} \times \mathrm{A}$

$\mathrm{P}=9 \times \mathrm{Rp} .4 .352 .400$

$\mathrm{P}=$ Rp. 39.171.600

Dari perhitungan biaya pemesanan optimal diatas dapat diketahui total biaya pemesanan optimal yaitu sebesar Rp. 1.199 .473 .200

3. Perhitungan Biaya Penyimpanan

Perhitungan biaya penyimpanan dapat dihitung dengan menggunakan rumus :

$$
S=l \times \mathrm{h}
$$

Dimana :

$$
\begin{aligned}
& l=\text { Rata-rata total inventory } \\
& l=\frac{Q}{2} \\
& h=\text { Ongkos simpan/unit } \\
& h=5 \% / \text { unit }
\end{aligned}
$$

Contoh perhitungan biaya penyimpanan untuk suku cadang DISC ASSY-CLUTCH sebagai berikut :

$S \quad=l \times h$

Hal pertama yang harus dilakukan adalah mencari nilai rata-rata inventory $(l)$, perhitungan nilai $l$ akan dijabarkan sebagai berikut :

$\begin{array}{ll}l & =\frac{45}{2} \\ l & =23\end{array}$

karena besarnya biaya simpan adalah sebesar $5 \%$ per unit maka,

$h=$ Rp. $806.000 \times 5 \%=$ Rp. 40.300

maka biaya simpan dapat diketahui sebagai berikut

$S \quad=l \times h$

$S \quad=23 \times$ Rp. 40.300

$S \quad=$ Rp. 926.900

Dari perhitungan biaya penyimpanan optimal diatas dapat diketahui total biaya penyimpanan optimal yaitu sebesar Rp. 154.229.425

Maka Total Biaya Persediaan Optimal dapat diketahui dengan perhitungan sebagai berikut :

$T C(\mathrm{Q})=\mathrm{S}+\mathrm{P}+\mathrm{O}$

$T C(\mathrm{Q})=$ Rp.154.229.425 + Rp. 1.199.473.200+

Rp. 5.630.959.000

$T C(\mathrm{Q})=$ Rp. 6.984.661.625

Jadi berdasarkan perhitungan total cost persediaan optimal (TCQ*) diatas, maka dapat diketahui bahwa besarnya total cost persediaan adalah sebesar Rp. 6.984.661.625

\section{Hasil dan Pembahasan}

1. Biaya Pembelian Perusahaan

Berdasarkan Perhitungan Biaya Pembelian Perusahaan dapat diketahui bahwa total biaya pembelian perusahaan dalam periode satu tahun adalah sebesar Rp. 10.116.658.500

2. Biaya Pemesanan Perusahaan

Berdasarkan perhitungan biaya pemesanan maka dapat diketahui besarnya total biaya pemesanan perusahaan adalah Rp 1.213.999.020

3. Biaya Penyimpanan Perusahaan

Berdasarkan perhitungan biaya penyimpanan perusahaan, maka dapat diketahui bahwa biaya penyimpanan perusahaan adalah sebesar Rp. 263.418.875

Setelah dilakukan perhitungan biaya penyimpanan maka, selanjutnya adalah memasukkan besarnya total biaya rumus total cost persediaan sebagai berikut :

$T C=S+P+O$

$T C=\quad$ Rp. $263.418 .875+\mathrm{Rp} 1.213 .999 .020+\mathrm{Rp}$.

10.116.658.500

$T C=\quad$ Rp. 11.594 .076 .395 
Jadi berdasarkan perhitungan total cost persedian diatas, maka dapat diketahui bahwa besarnya total cost persediaan yang dihitung sendiri oleh perusahaan adalah sebesar Rp. 11.594.076.395

\section{KESIMPULAN}

Berdasarkan hasil perhitungan data dan analisis pemecahan masalah yang telah dilakukan, maka dapat diambil kesimpulan sebagai berikut :

1. Total dari 1366 item kebutuhan perusahaan terhadap suku cadang unit Grand Livina, diperoleh 355 suku cadang unit Grand Livina yang kritis atau termasuk kategori golongan A.

2. Jumlah pengadaan sparepart unit Grand Livina yang optimal berdasarkan perhitungan EOQ multi item terdapat 355 item.

3. Total biaya persediaan yang dikeluarkan oleh perusahaan tahun 2018 adalah sebesar Rp. 11. 594.076.395, sedangkan total persediaan dengan menggunakan metode EOQ multi item adalah sebesar Rp. 6.984.661.625, dari kedua total biaya tersebut terdapat selisih antara kedua total biaya tersebut sebesar Rp. 4.609.414.770. Artinya dengan penetapan persediaan menggunakan metode EOQ multi item, maka perusahaan dapat menghemat total biaya persediaan sebesar Rp. 4.609.414.770 per satu periode yang dikeluarkan oleh perusahaan. Sehingga total biaya persediaan yang optimal dengan pengadaan suku cadang unit Grand Livina adalah sebesar Rp. 6.984.661.625.

\section{DAFTAR PUSTAKA}

1. Bahagia, Senator. Nur. 2006. Sistem Inventori. Bandung : Institut Teknologi Bandung

2. Heizer, Jay, dan Barry Render. 2015. Manajemen Operasi. Jakarta : Salemba Empat.

3. Ristono,Agus. 2013. Manajemen Persediaan. Yogyakarta. Graha Ilmu. 